\title{
Trace elements in soils of oases of Enderby Land (on an example of Vecherny oasis)
}

\author{
Tamara Kukharchyk $^{1 *}$, Sergey Kakareka ${ }^{1}$, Yury Giginyak ${ }^{2}$ \\ ${ }^{1}$ Institute for Nature Management of the National Academy of Sciences of Belarus, \\ Laboratory of Transboundary Pollution, Skoriny st. 10, Minsk, Belarus \\ ${ }^{2}$ The Scientific and Practical Centre for Bioresources of the National Academy of \\ Sciences of Belarus, Department of Monitoring and Cadastre of Fauna, Academicheskaya \\ st. 27, Minsk, Belarus
}

\begin{abstract}
The content of trace elements in the soils of the Vecherny Oasis (Enderby Land, East Antarctica), where the construction of the Belarusian Antarctic Station started in December 2015, is considered. The results of the research are based on data collected during four Belarusian Antarctic expeditions in the period from 2011 to 2017, and analytical testing of soil samples taken from impacted and non-impacted sites. A total of 22 soil samples were analyzed for the content of trace elements; to compare the levels of accumulation and possible migration pathways, 7 samples of bottom sediments were also analyzed. Determination of trace elements was carried out using the AAS method (Cd, $\mathrm{Cr}, \mathrm{Cu}, \mathrm{Pb}, \mathrm{Ni}, \mathrm{Zn}, \mathrm{Fe}, \mathrm{Mn}$ ) and emission spectral analysis (about 40 elements). The average values and range of concentrations of trace elements in soils and bottom sediments of the oasis are presented. The possible dependence of the trace elements content on the location positions in the landscape and on the sources of impact is discussed. It is shown, that the variability of metals content in soil profile for background site is low. In comparison with other oases of Antarctica no hotspots have been revealed and no significant areas of soil contamination have been identified yet, which is largely due to the fragmentation of the soil cover and lack of significant sources of pollution.
\end{abstract}

Key words: trace element, heavy metals, human impact, soil pollution, Belarusian Antarctic Station

DOI: $10.5817 / \mathrm{CPR} 2018-2-13$

\section{Introduction}

The content of trace elements in the soils of the Antarctic is one of the most important indicators of their state and environmental quality. Their accumulation and soil pollution connected with construction and operation of scientific stations, as well as actively developing touristic activities raise concern regarding the possible nega-

Received August 29, 2018, accepted December 17, 2018.

*Corresponding author: T. Kukharchyk <tkukharchyk@gmail.com>

Acknowledgements: Authors express sincerely thankful to members of BAE Alexei Haidashou and Vladislav Myamin for soil and bottom sediments sampling. 
tive impact on unique polar ecosystems (Chen et Blume 1995, Bargagli 2000, 2008; Tin et al. 2009, Braun et al. 2014, O'Neill et al. 2015, O'Neill 2017).

Soils of the Antarctic oases formed in extreme climatic conditions are characterized by slow soil-forming processes that caused their vulnerability to environmental change and anthropogenic impacts (Campbell et Claridge 1987, Ugolini et Bockheim 2008, O'Neill et al. 2015). As it was noted in (Bargagli 2000), the deposition of trace elements with long-range transport to the Antarctic is generally insignificant (with the exception of lead). The input of local sources is predominance for soil contamination in impact zones of scientific stations. Up to now, high levels of heavy metals were recorded at waste storage sites at McMurdo Station (Claridge et al. 1995), Scott Base (Sheppard et al. 2000), Casey station (Stark et al. 2008), around the Marambio station (Chaparro et al. 2007), at the former Vanda base (Webster et al. 2003), on the island of King George Fields Peninsula ( $\mathrm{Lu}$ et al. 2012, Padeiro et al. 2014), on the Marina Point at the Argentine Islands (Parnikoza et al. 2016), etc. In a number of cases, a very significant chemical transformation of the original soils has been identified due to their contamination, as was the case in the vicinity of Trinity House and Nordenskjold Hut at Hope Bay (Antarctic Peninsula); this allowed to classify soils as technosols (Guerra et al. 2011). Regarding the soil pollution, the most evident cases are caused by anthropogenic loads connected with high density of stations functioning for a long time ( $\mathrm{Lu}$ et al. 2012, Celis et al. 2015, Padeiro et al. 2016). The danger of soil contamination in the Antarctic oasis, even within the local areas, is associated with pollutants re-distribution and their entry into terrestrial water and coastal seas and their subsequent accumulation in sediments and biota (Santos et al. 2005, Kennicutt et al. 2010, Fryirs et al. 2015). In some cases, remediation of metal-contaminated soils has been needed (Snape et al. 2001, Taylor 2015).

Investigation of trace elements content in soils of Antarctic oases as well as main properties of soils and the structure of the soil cover are very different. According to (Bockheim 2015), more than $75 \%$ of the soil samples collected in the Antarctic come from the Transantarctic region of the Victoria Land and 16\% - from the Antarctic Peninsula. According to (Szopinska et al. 2016), more than half of all studies related to the determination of pollutants in the environment until 2014 have been carried out in the Sea of Ross and South Shetland Islands. The share of East Antarctica accounts for about $18 \%$ of all studies. Recent publications on the soils of the oases of East Antarctica refer to the specific features of soil formation and the properties of soils in this region (Mergelov 2014, Mergelov et al. 2015, Dolgikh et al. 2015, Zazovskaya et al. 2016). As for the Enderby Land, the available data on soils are scarce and fragmentary (MacNamara 1969, Simonov 1971, Aleksandrov 1985, Dolgikh et al. 2015). Regarding the trace element content, data was not found.

The object of our investigation - oasis Vecherny, where the construction of the Belarussian Antarctic station started in 2015 after consideration and approval of Comprehensive Environmental Evaluation at XXXVIII ATCM in Sofia, Bulgaria. By now, the basic infrastructure has been created, including several residential and service models, diesel generators, etc. The station operates in seasonal mode (5-8 people); in the future it is planned to move to a year-round mode with a staff of about 12 people.

Between 1980 and 1991, the field base 'Vechernyaya Mountain' of the Soviet Antarctic Expedition (SAE) functioned here in the year-round mode, to provide operation of the airfield. To date, the remaining infrastructure of the field base has been partially dismantled. A few old facilities are 
used now, and a few of them are abandoned.

Objective of the research: to determine the content of trace elements in the soils of the Vecherny oasis and to reveal the fea-

\section{Material and Methods}

The investigations were carried out in the Vecherny oasis located in the western part of Enderby Land at the Tala Hills (eastern part), in the coastal zone of the Alasheev Bay of the Cosmonauts Sea. There are a number of rocky ridges with a dominant height - Vechernyaya Mountain $(272.0 \mathrm{~m})$ and several lower ridges stretched almost parallel to the shore with a northwest - south-east orientation. The northeastern slopes of the ridges are steep and short, sometimes precipitous, and the southwestern ones are gentle. The ridges are separated by terraced valleys, the bottoms of which are occupied by glaciers and temporary watercourses. The eastern boundary of the region is the excurrent Hayes glacier. The nearest oasis Molodezhny is at a distance of $20 \mathrm{~km}$. The area of the territory that is not covered by ice in the Vecherny oasis is about $6 \mathrm{~km}^{2}$; for comparison, icefree area in Molodezhny oasis - $10 \mathrm{~km}^{2}$, Schirmacher oasis - $35 \mathrm{~km}^{2}$, Vestfold oasis $-400 \mathrm{~km}^{2}$, South Shetland islands $500 \mathrm{~km}^{2}$, McMurdo Dry Valleys - 6700 $\mathrm{km}^{2}$ (Bockheim 2015).

Soil sampling was carried out by the participants of the $4^{\text {th }}, 5^{\text {th }}, 7^{\text {th }}$ and $8^{\text {th }}$ Belarusian Antarctic expeditions (BAE) in the period from 2011 to $2017 \mathrm{Yu}$. Giginyak, V. Myamin and A. Haidashou. In total, during the four expeditions, 15 points were laid in areas with loose sediments and 70 soil samples were taken. Soil sampling was collected at two background areas (remote from direct anthropogenic impact) and at three sites that were used before by SAE or are used now for the construction of Belarusian Antarctic station. tures of their accumulation, taken into account the soil forming factors and human impact. The results of the work will be used as a starting point for the subsequent monitoring and impact assessment.

Location of soil sampling points is shown on Fig. 1.

The short description of investigated areas is given below.

Site I: the territory north of Lake Nizhnee, $0.7 \mathrm{~km}$ from the residential modules of Belarusian Antarctic station. It is separated by ridges from the sea, as well as from the former field base and Belarusian Antarctic station so it can be considered as a background one. Loose deluvial and fluvioglacial deposits cover several tens of square meters. Feathers of skuas are found on the surface. Vegetation is absent. A soil pit (point 3) with a depth of $55 \mathrm{~cm}$ was allocated.

Site II: the territory to the east of BAS at the distance $1 \mathrm{~km}$; the area of moraine deposits location. Direct anthropogenic and ornithogenic impact are not present. Surface is a slightly inclined. Loose deposits were revealed at the area of a few tens of square meters. The vegetation is presented by mosses. Tree soil pits (points 50, 70 and 75) with a depth from 30 to $65 \mathrm{~cm}$ was allocated.

Site III: a territory formed by alluvial and fluvioglacial deposits of permanent streams near Lake Nizhneye. Impacted by the SAE field base in the $1980-1990^{\text {th }}$ as well as by station construction site (with meltwater). The thickness of soil is up to $15-20 \mathrm{~cm}$. Vegetation is absent.

Site IV: a gentle slope with depressions and temporary streams; buildings of the former field base are located here. Mainly short-profiled soils (up to $20 \mathrm{~cm}$ ) on eluvial and deluvial deposits are presented. There are few cenoses with mosses and algae. 
Site V: rocky wavy terrace with temporary streams; station construction areas; the soils are predominantly thin (up to $20 \mathrm{~cm}$ ) on eluvial and deluvial deposits. One cenose with mosses is found.

In most cases, surface soil samples were collected from the entire soil profile (usually up to $15-20 \mathrm{~cm}$ ). When the soil pits were excavated, samples have been taken by the horizons (for example, pit 3: $0-5$, 5-10, 10-20, 20-30, 30-40, 40-50 and 50$55 \mathrm{~cm}$; pit 50: 0-2, 2-10, 10-20, 20-30 cm).

Samples of bottom sediments from permanent lakes as well as from temporary lakes, which are fed mainly by snowmelt, were selected for a preliminary assessment of the possible migration of trace elements.

The general characteristics of soil sampling sites are given in Table 1.

Samples of soils and bottom sediments were collected in plastic containers and stored in a cold place until delivery to Belarus.

Sample preparation of soils was carried out in a chemical analytical laboratory at the Institute of Nature Management (Minsk) according to ISO 11464. Samples of soils and bottom sediments were dried and sieved through $1 \mathrm{~mm}$ sieve. For chemical analyses a fraction of less than $1 \mathrm{~mm}$ was used.

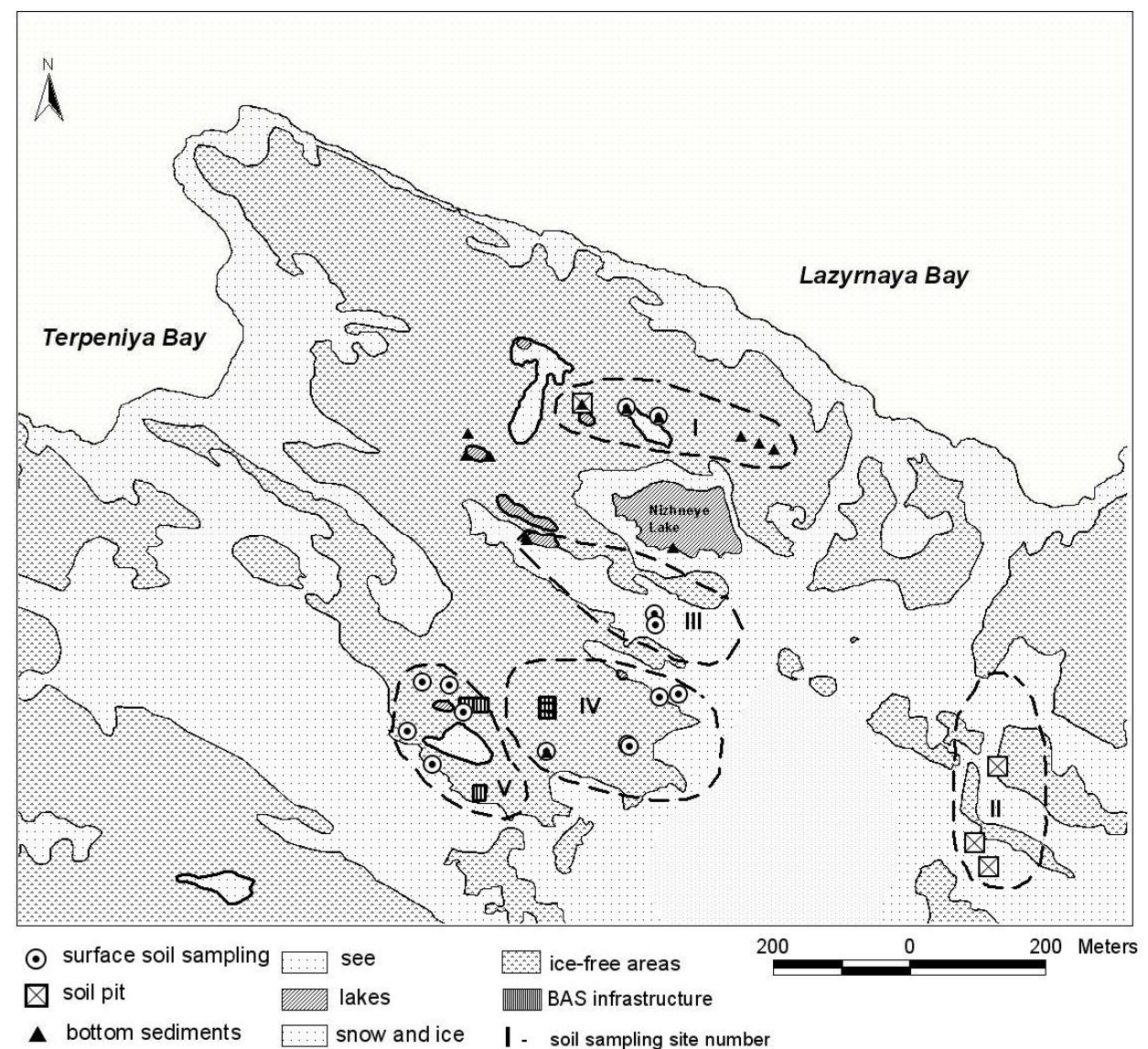

Fig. 1. Location of soil sampling points at Vecherny oasis. 
TRACE ELEMENTS IN SOILS

\begin{tabular}{|c|c|c|c|c|c|c|}
\hline $\begin{array}{l}\text { Investigated } \\
\text { site (amount } \\
\text { of soil } \\
\text { sampling } \\
\text { points) }\end{array}$ & $\begin{array}{l}\text { Type of } \\
\text { samples, } \\
\text { depth }\end{array}$ & $\begin{array}{l}\text { Altitude } \\
\text { (m) }\end{array}$ & $\mathbf{p H}_{\mathrm{KCl}}$ & $\begin{array}{c}\text { Humus } \\
(\%)\end{array}$ & $\begin{array}{c}\text { The } \\
\text { share of } \\
\text { fraction } \\
<1 \mathrm{~mm} \\
(\%)\end{array}$ & $\begin{array}{c}\text { Possible sources } \\
\text { of pollutants }\end{array}$ \\
\hline Site I (3) & $\begin{array}{l}\text { Soil pits: } \\
\text { samples by } \\
\text { horizons. } \\
\text { Surface, } \\
0-15 \\
\end{array}$ & $43-47$ & $4.0-5.7$ & 2.4-4.3 & $15-64$ & $\begin{array}{l}\text { Background area } \\
\text { to the north from } \\
\text { station; separated } \\
\text { from the BAS by } \\
\text { a ridge }\end{array}$ \\
\hline Site II (3) & $\begin{array}{l}\text { Soil pits: } \\
\text { samples by } \\
\text { horizons. }\end{array}$ & 95 & 6.4 & 0.16 & 67 & $\begin{array}{l}\text { Background area } \\
\text { to the east from } \\
\text { station (about } \\
1 \mathrm{~km} \text { ) }\end{array}$ \\
\hline Site III (2) & $\begin{array}{l}\text { Surface, } \\
0-20\end{array}$ & $42-43$ & $5.0-5.4$ & - & $15-97$ & $\begin{array}{l}\text { Area of the past } \\
\text { activities of the } \\
\text { field base in } \\
1980-1990^{\text {th }} \text {; melt } \\
\text { water from Sites } \\
\text { IV and V }\end{array}$ \\
\hline Site IV (5) & $\begin{array}{l}\text { Surface, } \\
0-20\end{array}$ & $70-84$ & $5.2-5.6$ & 0.16 & $31-71$ & $\begin{array}{l}\text { Area of the past } \\
\text { activity of the } \\
\text { field base in } \\
1980-1990^{\text {th }} \text {; } \\
\text { residential } \\
\text { buildings; melt } \\
\text { water from } \\
\text { Sites V }\end{array}$ \\
\hline Site V (5) & $\begin{array}{l}\text { Surface, } \\
0-15\end{array}$ & $77-95$ & $4.5-5.6$ & $0.09-2.24$ & $77-95$ & $\begin{array}{l}\text { Current activity } \\
\text { (Belarusian } \\
\text { Antarctic station } \\
\text { construction and } \\
\text { operation); fuel } \\
\text { storage area }\end{array}$ \\
\hline
\end{tabular}

Table 1. General characteristic of soil samples collection sites at Vecherny oasis.

Determination of $\mathrm{Cd}, \mathrm{Cr}, \mathrm{Cu}, \mathrm{Pb}, \mathrm{Ni}$, $\mathrm{Zn}$ and $\mathrm{Mn}$ was performed by atomic absorption spectrometric (AAS) method according to ISO 11047. A flame atomic absorption spectrometer (Saturn-3) was used. The concentration of elements was detected in an aqua regia extract of the sample prepared in accordance with ISO 11466. $\mathrm{HCl}$ and $\mathrm{HNO}_{3}$ in proportion 3:1 was used for acid digestion of sample. Stock solution of all elements has been prepared using the state standard sample (SSS): SSS070-12-93; SSS7874-2000; SSS78732000; SSS7836-2000; SSS7837-2000.
Before conducting of each series of experiments, at least five calibration solutions has been prepared covering the concentration range of the element being determined. Calibration lines for each element was created. A blank sample was used as a zero. The accuracy of digestion and analytical procedures was verified for each batch of samples through analysis of reagent blanks and determination of elemental concentrations in Standard Reference Material (Lead-zinc Concentrate 68075; Bismut copper concentrate 616-75). The detection limit for Cd was $0.007 \mathrm{mg} / \mathrm{l}$, 
$\mathrm{Pb}-0.05, \mathrm{Cu}-0.004, \mathrm{Ni}-0.02, \mathrm{Zn}-$ $0.004, \mathrm{Cr}-0.005$ and $\mathrm{Mn}-0.004 \mathrm{mg} / \mathrm{l}$. Quality control was evaluated by duplicate analysis. The relative standard deviations for all measured metal concentrations were lower than $25 \%$.

Determination of $\mathrm{Co}, \mathrm{V}, \mathrm{Ti}, \mathrm{Mo}, \mathrm{Zr}$, $\mathrm{Nb}, \mathrm{Ge}, \mathrm{La}, \mathrm{Y}, \mathrm{Yb}, \mathrm{Ga}, \mathrm{Bi}, \mathrm{Sc}, \mathrm{Sn}, \mathrm{Li}, \mathrm{B}$, $\mathrm{Ba}, \mathrm{W}, \mathrm{As}, \mathrm{Sb}, \mathrm{Hf}, \mathrm{Ta}, \mathrm{Ag}, \mathrm{U}, \mathrm{Th}, \mathrm{Be}, \mathrm{Sr}$ and In was carried out by emission spectral analysis. For spectral emission analysis, samples have been ground and homogenized. Internal standards were used for spectral lines identification. Quantitative assessment of the element content has been done with the usage of calibration graphs. Standard Reference Material (Shale and Basalt) with fixed content of trace elements were used for analytical procedures. The relative standard deviations for

\section{Results}

According to the results, the following mean concentrations of trace elements were obtained, $\mathrm{mg} / \mathrm{kg}$ : $\mathrm{Cd}-0.75, \mathrm{~Pb}-9.9$, $\mathrm{Cu}-19.2, \mathrm{Zn}-42.9, \mathrm{Ni}-9.6, \mathrm{Cr}-21.9$, $\mathrm{Fe}-9754, \mathrm{Mn}-114.5$, Co - 23.7, V - 60, $\mathrm{Ti}-1430, \mathrm{Mo}-0.8, \mathrm{Zr}-15, \mathrm{Nb}-1.1$, $\mathrm{Ge}-1.7, \mathrm{Y}-12, \mathrm{Yb}-3.5$, Ga - 10.9, $\mathrm{Sn}-2.8, \mathrm{P}-545, \mathrm{Li}-3.3, \mathrm{~B}-5.2$ (see Table 2). Content of $\mathrm{La}, \mathrm{Bi}, \mathrm{Sc}$ and $\mathrm{Ba}$ was detected in less than $50 \%$ of samples; for these element mean values were not estimated. Content of W, As, Sb, Hf, Ta, Ag, $\mathrm{U}, \mathrm{Th}, \mathrm{Be}, \mathrm{Sr}$ and In was below the detection limit in all samples.

Comparison with Upper Continental Crust (UCC) given in (Rudnick et Gao 2003) has shown, that content of most elements (including $\mathrm{Pb}, \mathrm{Cu}, \mathrm{Zn}$ ) in soil of oasis Vecherny is comparable with UCC. Content of $\mathrm{Cd}, \mathrm{Ni}, \mathrm{Cr}$ and $\mathrm{V}$ is more corresponded with their content in podzolic soil according to (Kabata-Pendias et Pendias 2001). Concentrations of $\mathrm{Mn}, \mathrm{Zr}$, trace element content were lower than $20 \%$.

Determination of trace elements was done in the laboratory of the Institute for Nature Management and in the laboratory of State Enterprise 'Research and Production Center for Geology'. To check the procedure accuracy, inter-laboratory measures were undertaken.

Trace element concentrations are expressed in $\mathrm{mg} / \mathrm{kg}$ dry weight.

Statistical methods for analysis of trace element content in soil was applied to calculate average content and standard error.

In the total of 22 soil samples and 7 bottom sediments were analyzed.

Content of major elements, humus, $\mathrm{pH}$ as well as the share of fraction of less than $1 \mathrm{~mm}$ have been also determined.

$\mathrm{Nb}, \mathrm{Sc}, \mathrm{Ba}$ and $\mathrm{Li}$ in soils of oasis Vecherny are significant less than in the UCC.

In bottom sediments mean content of trace elements was as follow: $\mathrm{Cd}-1.2$, $\mathrm{Pb}-18.2, \mathrm{Cu}-43.0, \mathrm{Zn}-83.4, \mathrm{Ni}-20.0$, $\mathrm{Cr}-23.3, \mathrm{Fe}-10013, \mathrm{Mn}-164.0$, $\mathrm{Co}-12.0, \mathrm{~V}-33.0, \mathrm{Ti}-430, \mathrm{Mo}-1.3$, $\mathrm{Zr}-15.0, \mathrm{Nb}-1.5, \mathrm{Ge}-1.5, \mathrm{Y}-23.0$, $\mathrm{Yb}-2.8, \mathrm{Bi}-1.3, \mathrm{Ga}-6.0, \mathrm{Sc}-5.0$, $\mathrm{Sn}-3.0, \mathrm{~B}-17.0$. Content of W, As, Sb, Hf, Ta, Ag, U, Th, Be, Sr and In was below the detection limit. Mean concentrations were not estimated for $\mathrm{La}, \mathrm{Ba}$ and $\mathrm{Li}$ as their concentration was detected in less than $50 \%$ of samples.

For analysis all samples of soil were separated for two parts represented background sites and sites with possibility anthropogenic impact. The main parameters of trace elements content (which is belong to heavy metals) for these cases are presented in the Table 3. 


\begin{tabular}{|c|c|c|c|c|c|c|c|c|}
\hline \multirow{2}{*}{$\mathbf{E}$} & \multicolumn{3}{|c|}{ Soil } & \multicolumn{3}{|c|}{ Bottom sediments } & \multirow{2}{*}{$\begin{array}{c}\text { Mean } \\
\text { A }\end{array}$} & \multirow{2}{*}{$\begin{array}{c}\text { Mean } \\
\text { B }\end{array}$} \\
\hline & Range & $\begin{array}{c}\text { Mean } \\
\pm \text { st.error }\end{array}$ & $\begin{array}{l}\text { Oc } \\
(\%)\end{array}$ & Range & $\begin{array}{c}\text { Mean } \\
\pm \text { st.error }\end{array}$ & $\begin{array}{l}\text { Oc } \\
(\%)\end{array}$ & & \\
\hline $\mathrm{Cd}^{1}$ & nd-2.09 & $0.75 \pm 0.18$ & 86 & $0.14-2.42$ & $1.2 \pm 0.32$ & 100 & $0.09 \pm 0.01$ & 0.37 \\
\hline $\mathrm{Pb}$ & nd-22.8 & $9.9 \pm 2.1$ & 86 & nd-36.3 & $18.2 \pm 4.5$ & 86 & $17.0 \pm 0.5$ & 22 \\
\hline $\mathrm{Cu}$ & $9.0-30.2$ & $19.2 \pm 1.1$ & 100 & $12.4-78.5$ & $43.0 \pm 9.7$ & 100 & $28 \pm 4.0$ & 13 \\
\hline $\mathrm{Zn}$ & $10.2-172.9$ & $42.9 \pm 8.6$ & 100 & $13.1-162.8$ & $83.4 \pm 19.7$ & 100 & $67 \pm 6$ & 45 \\
\hline $\mathrm{Ni}$ & $0.52-30.7$ & $9.6 \pm 2.5$ & 100 & $2.0-37.5$ & $20.0 \pm 5.8$ & 100 & $47 \pm 11$ & 13 \\
\hline $\mathrm{Cr}$ & $4.2-57.9$ & $21.9 \pm 4.5$ & 100 & $5.2-43.5$ & $23.3 \pm 6.0$ & 100 & $92 \pm 17$ & 47 \\
\hline $\mathrm{Mn}$ & $56.7-160$ & $114 \pm 18$ & 100 & $98.4-214$ & $164 \pm 12$ & 100 & $774 \pm 116$ & 270 \\
\hline $\mathrm{Co}^{2}$ & $10.0-70.0$ & $23.7 \pm 4.7$ & 100 & $7.0-20.0$ & $12.0 \pm 3.9$ & 100 & $17.3 \pm 0.6$ & 5.5 \\
\hline $\mathrm{V}$ & $30.0-70.0$ & $60.0 \pm 3.3$ & 100 & $20.0-50.0$ & $33.0 \pm 8.8$ & 100 & $97 \pm 11$ & 67 \\
\hline $\mathrm{Ti}$ & $200-3000$ & $1430 \pm 230$ & 100 & $300-500$ & $430 \pm 67$ & 100 & $3900 \pm 585$ & 2600 \\
\hline Mo & $0.5-1.0$ & $0.8 \pm 0.07$ & 100 & $0.5-3.0$ & $1.3 \pm 0.8$ & 100 & $1.1 \pm 0.3$ & 1.3 \\
\hline $\mathrm{Zr}$ & $5.0-30.0$ & $15.0 \pm 2.7$ & 100 & $5.0-30.0$ & $15.0 \pm 7.6$ & 100 & $197 \pm 28$ & $160^{4}$ \\
\hline $\mathrm{Nb}$ & nd-3.0 & $1.1 \pm 0.2$ & 67 & nd-3.0 & $1.5 \pm 0.9$ & 67 & $12 \pm 1$ & - \\
\hline $\mathrm{Ge}$ & $0.5-3.0$ & $1.7 \pm 0.3$ & 100 & $0.5-3.0$ & $1.5 \pm 0.8$ & 100 & $1.4 \pm 0.1$ & - \\
\hline $\mathrm{La}$ & nd-30.0 & - & 27 & nd-30.0 & - & 33 & $31 \pm 3$ & $37.4^{4}$ \\
\hline $\mathrm{Y}$ & nd-30.0 & $12.0 \pm 2.4$ & 80 & $10.0-30.0$ & $23.0 \pm 6.7$ & 100 & $21 \pm 2$ & - \\
\hline $\mathrm{Yb}$ & $1.0-7.0$ & $3.5 \pm 0.7$ & 100 & $0.5-7.0$ & $2.8 \pm 2.1$ & 100 & $1.96 \pm 0.4$ & $4.0^{4}$ \\
\hline $\mathrm{Bi}$ & nd- 0.5 & - & 27 & nd-2.0 & $1.3 \pm 0.7$ & 67 & $0.16 \pm 0.06$ & - \\
\hline $\mathrm{Ga}$ & $7.0-30.0$ & $10.9 \pm 1.4$ & 100 & $3.0-10.0$ & $6.0 \pm 2.1$ & 100 & $17.5 \pm 0.7$ & - \\
\hline $\mathrm{Sc}$ & nd-10.0 & - & 47 & 5.0 & $5.0 \pm 0$ & 100 & $14.0 \pm 0.9$ & 5 \\
\hline $\mathrm{Sn}$ & $<1-5.0$ & $2.8 \pm 0.4$ & 93 & $1.0-7.0$ & $3.0 \pm 2.0$ & 100 & $2.1 \pm 0.5$ & - \\
\hline $\mathrm{Ba}$ & nd-50.0 & - & 7 & nd-200 & - & 33 & $628 \pm 83$ & 330 \\
\hline $\mathrm{Li}$ & nd-5.0 & $3.3 \pm 0.6$ & 67 & nd & - & 0 & $24 \pm 5$ & 22 \\
\hline $\mathrm{B}$ & $1.5-10.0$ & $5.2 \pm 0.9$ & 100 & $10.0-30.0$ & $17.0 \pm 6.7$ & 100 & $17 \pm 8$ & 22 \\
\hline
\end{tabular}

Table 2. Trace elements content in soil of oasis Vecherny, $\mathrm{mg} / \mathrm{kg}$.

Notes: E - Elements, Oc - Occurrence, Mean A - Mean content in upper continental crust (Rudnick et Gao 2003) , $^{3}$, Mean B - Mean content in podzols soil (Kabata-Pendias et Pendias 2001) ${ }^{1}$ - elements from Cd to Mn have been determined by AAS; ${ }^{2}$ - elements from Co to B - by emission spectral analysis; ${ }^{3}$ - average content \pm standard deviation; ${ }^{4}$ - average content in soil (Kabata-Pendias 2010).

The results shown that more significant variability of heavy metals content especially $\mathrm{Cd}, \mathrm{Pb}, \mathrm{Zn}$ and $\mathrm{Cr}$ is characteristic for the areas where human activity has been done in the past and/or are continued now. The mean content for the background area is estimated as follows: $\mathrm{Cd}-0.12 \mathrm{mg} / \mathrm{kg}$,
$\mathrm{Pb}-4.6, \mathrm{Cu}-22.1, \mathrm{Zn}-23.0, \mathrm{Ni}-14.1$ and $\mathrm{Cr}-10.2 \mathrm{mg} / \mathrm{kg}$. The mean content of $\mathrm{Cd}$ in soil of impacted sites approximately 10 times more in comparison with the background area, $\mathrm{Pb}-3.3, \mathrm{Zn}-2.6$ and $\mathrm{Cr}$ - 3.2 times. Close data has been received regarding $\mathrm{Ni}$ and $\mathrm{Cu}$. 


\begin{tabular}{|c|c|c|c|c|c|c|c|}
\hline Site & Par. & Cd & $\mathbf{P b}$ & $\mathrm{Cu}$ & Zn & $\mathbf{N i}$ & $\mathrm{Cr}$ \\
\hline \multirow{2}{*}{$\begin{array}{l}\text { Non } \\
\text { impacted } \\
\text { site (I-II) }\end{array}$} & Range & nd -0.22 & nd-15.0 & $9.0-30.0$ & $10.3-40.0$ & $1.2-50.0$ & $4.6-20.0$ \\
\hline & $\begin{array}{c}\text { Mean } \\
\pm \text { STD }\end{array}$ & $0.12 \pm 0.09$ & $4.6 \pm 1.2$ & $22.1 \pm 2.1$ & $23.0 \pm 2.7$ & $14.1 \pm 6.2$ & $10.2 \pm 1.7$ \\
\hline \multirow{2}{*}{$\begin{array}{l}\text { Impacted } \\
\text { sites } \\
(\text { III-V) }\end{array}$} & Range & & nd -22.8 & $10.6-30.2$ & $10.2-172.9$ & $0.5-30.7$ & $4.2-57.9$ \\
\hline & $\begin{array}{c}\text { Mean } \\
\pm \text { STD }\end{array}$ & $1.19 \pm 0.24$ & $15.0 \pm 2.8$ & $19.0 \pm 1.3$ & $59.7 \pm 12.6$ & $14.7 \pm 3.1$ & $32.3 \pm 6.2$ \\
\hline
\end{tabular}

Table 3. Mean content of heavy metals by sampling sites. Notes: Par. - parameter, STD - standard error.

It should be stressed that the highest content of zinc $(172.9 \mathrm{mg} / \mathrm{kg})$, chromium 57.9 , lead - 22.8, cadmium - $2.09 \mathrm{mg} / \mathrm{kg}$ was revealed in the soil near the temporary watercourse (Sample 1, Site III). It means that migration of contaminants with meltwater is possible. The detected concentrations within Site III are similar to the levels in the lakes bottom sediments, which may confirm a redistribution of pollutants and their accumulation in lakes.

The detected concentrations within Site III are similar to the levels in the lakes bottom sediments, which may confirm a redistribution of pollutants and their accumulation in lakes.

Compared with the mean concentration values for the soils of the Vecherny oasis, concentration in lakes sediments is 2.3 times higher for nickel, 2.1 times -for copper, 2 -for zinc, 1.9 -for lead, and 1.6 -for cadmium (Fig. 2).

The distribution of heavy metals through the soil profile (Table 4) is considered on an example of a soil pit (3) which was dug outside the impact zone (on Site I).

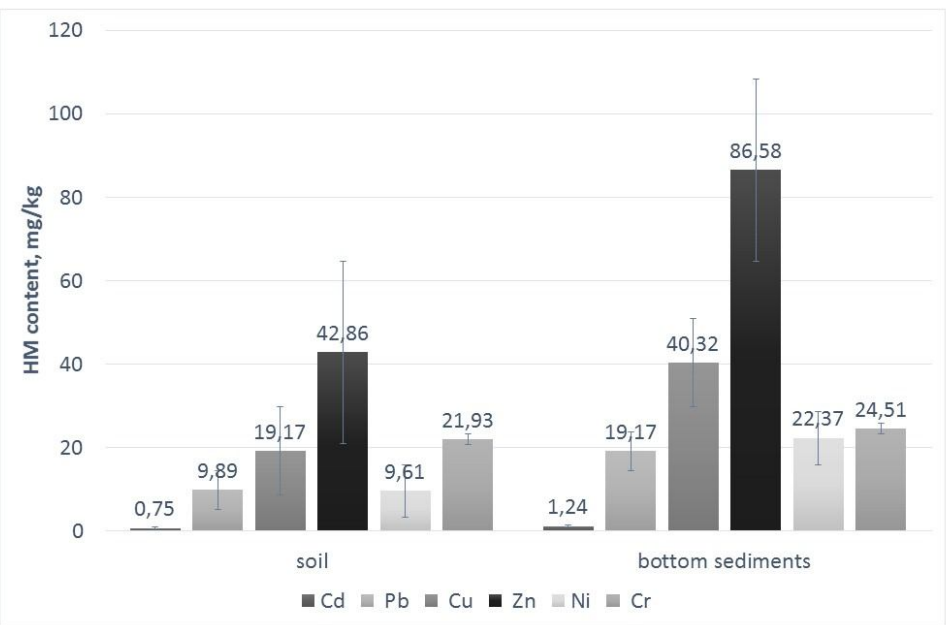

Fig. 2. Comparison of mean heavy metals content in soils and bottom sediments of Vecherny oasis (error bars are shown). 


\begin{tabular}{|c|c|c|c|c|c|c|c|c|}
\hline $\begin{array}{c}\text { Sampling } \\
\text { depths, cm }\end{array}$ & $\begin{array}{c}\text { The share } \\
\text { of fraction } \\
<1 \mathrm{~mm} \%\end{array}$ & $\begin{array}{c}\text { Loss on } \\
\text { ignition, } \\
\%\end{array}$ & $\mathrm{Cd}$ & $\mathrm{Pb}$ & $\mathrm{Cu}$ & $\mathrm{Zn}$ & $\mathrm{Ni}$ & $\mathrm{Cr}$ \\
\hline $0-5$ & 64.5 & 1.7 & $<$ & $<1$ & 15.3 & 18.6 & 1.9 & 6.9 \\
\hline $5-10$ & 73.6 & 1.8 & $<$ & 3.2 & 17.6 & 18.2 & 2.2 & 7.6 \\
\hline $10-20$ & 67.1 & 1.4 & $<$ & 2.0 & 19.6 & 17.3 & 2.2 & 6.4 \\
\hline $20-30$ & 76.1 & 1.8 & 0.16 & 4.3 & 24.3 & 22.0 & 2.7 & 7.2 \\
\hline $30-40$ & 76.6 & 1.4 & 0.11 & 3.5 & 29.6 & 22.7 & 2.7 & 7.6 \\
\hline $40-50$ & 62.3 & 1.2 & 0.21 & 2.2 & 19.9 & 17.8 & 2.2 & 6.6 \\
\hline $50-55$ & 60.1 & 1.3 & 0.22 & 2.2 & 13.7 & 15.7 & 1.8 & 6.0 \\
\hline
\end{tabular}

Table 4. Distribution of heavy metals by soil profile (pit 3, Site I), $\mathrm{mg} / \mathrm{kg}^{l}$.

${ }^{I}$ the relative standard deviations for all measured metal concentrations were lower than $25 \%$.

According to the obtained results, the cadmium content is below the detection limit up to the depth of $20 \mathrm{~cm}$; deeper it ranges from 0.11 to $0.22 \mathrm{mg} / \mathrm{kg}$. The lead content in the surface horizon is less than $1 \mathrm{mg} / \mathrm{kg}$, it increases with the depth; the maximum values $(4.3 \mathrm{mg} / \mathrm{kg})$ are confined to the horizon of $20-30 \mathrm{~cm}$. The minimum values of copper $(13.7 \mathrm{mg} / \mathrm{kg})$, zinc (15.7), nickel (1.8) and chromium $(6.0 \mathrm{mg} / \mathrm{kg})$ were detected at the depth 50-55 cm; maximum values $(29.6 \mathrm{mg} / \mathrm{kg}$ copper, $22.7 \mathrm{mg}$ / $\mathrm{kg}$ zinc, $2.7 \mathrm{mg} / \mathrm{kg}$ nickel and $7.6 \mathrm{mg} / \mathrm{kg}$ chromium) - at the depth $30-40 \mathrm{~cm}$. In general, the variability of heavy metals content is low; elevated concentration of heavy metals on the depths $20-40 \mathrm{~cm}$ may results of the processes of metal redistribution with fine soil particles $(<1 \mathrm{~mm})$. The max-

\section{Discussion}

Variability of trace elements content in the soils of the Vecherny oasis can be caused by both natural and anthropogenic factors. It can be assumed that one of the most important natural factors determining the initial concentrations of trace elements is the composition and properties of parent rocks, as shown by the example of other stations (Crockett 1998, Malandrino et al. 2009, Kostova et al. 2015, Vlček et al. 2017, Smykla et al. 2018, Sheppard et al. imum share of this fraction $(76.1-76.6 \%)$ was found here (in the surface horizon its share is $64.5 \%$, at a depth of $50-55 \mathrm{~cm}-$ $60.1 \%$ ). Loss on ignition varies insignificantly between soil samples: from $1.8 \%$ in the surface horizon, to $1.2 \%$ in the underlying horizon. This means that the influence of organic matter to the heavy metals distribution in soil profile is probably not important. According to (Zvěřina et al. 2012), the key role in maximum concentrations of $\mathrm{Cr}, \mathrm{Cu}, \mathrm{Ni}$ and $\mathrm{Zn}$ fixed at depths of 2 to $20 \mathrm{~cm}$ in soil of the coastal zone of James Ross Island belong to increased content of clay minerals and iron oxyhydroxides in this horizon that have a high sorption capacity and can accumulate heavy metals.

2000). According to the data (Myasnikov 2011, Karataev et Garetsky 2011), metamorphic rocks of the Archaean and Proterozoic ages are represented in the Vecherny oasis: plagiogneisses, enderbite-charnockites, charnockite gneisses and augen-gneisses; for granitoids of the charnockite stratum, signs of an increased content of Fe, $\mathrm{Ti}, \mathrm{Cu}$, and $\mathrm{Zn}$ elements have been revealed. The different intensity of the processes of physical and chemical weathering of lo- 
cal rocks, as well as the introduction of moraine deposits create the prerequisites for initial differences in soils.

Preliminary data on the grain size distribution and mineralogical features of soils of the Vecherny oasis have shown that soils are represented mainly by sand of different fractions (Kukharchyk et Kakareka 2016). The primary minerals, first of all quartz and feldspar are dominated in the soil samples. It has been established, that when the fraction size is decreased, the share of quartz is increased (reaching $80 \%$ for the fraction $0.16 \mathrm{~mm}$ ). With increasing fraction size, the share of granite, feldspar and diorite is increased (up to $71 \%$ in the $2.5 \mathrm{~mm}$ fraction). The semi-crocked and angular-rounded form of quartz and granite grains and other minerals indicates the influence of water flows on the soil-forming process as a result of seasonal snowmelt.

The chemical properties of soils, including the content of trace elements, are influenced as well by other natural factors that determine the intensity of physical and chemical weathering. The soils of the Vescherny oasis, like many other oases, have a low organic matter content and exchange bases (Kukharchyk et Kakareka 2016). They are fragmentary and differ in properties even within small investigated areas. For example, the share of fine fraction (less than $1 \mathrm{~mm}$ ) in Site III varies from 15 to $97 \%$, in Site I - from 15 to $64 \%$, in Site IV - from 31 to $71 \%$. The $\mathrm{pH}$ value in soil samples collected at Site III varies from 4.6 to 5.6, and the humus content is from 0.09 to $2.24 \%$. It is corresponding with the results given in (Campbell et Claridge 1987), was shown that the properties of soils differ significantly even within an oasis, depending on the location in the relief, the exposure of slopes, remoteness from the shoreline, moisture, vegetation, distance from penguin nesting grounds and other factors.

The cases of elevated concentrations of heavy metals in the soils and bottom sedi- ments of the Vecherny oasis may be considered as a results of chemical elements migration with water flows. Since the water flows pass through the territory where the SAE field base facilities were formerly located, as well as the Belarusian Antarctic station fuel storage site, it is possible to assume an anthropogenic contribution to the increased concentrations of heavy metals. In the future, this factor should be given special attention, since a lot of watercourses are appeared in summer, which is caused by significant differences in the altitude between investigated areas: from $42 \mathrm{~m}$ to $95 \mathrm{~m}$.

It should be stressed that the identification of natural and anthropogenic factors of accumulation of heavy metals in the soils of Antarctica is a complex process, which require conduction of detailed studies and the collection of data for poorly investigated areas. First of all, it is necessary to establish background concentrations for different soil parameters, taking into account the parent rocks and their location in the relief. The importance of the initial environmental conditions which determine the heterogeneity of metals distribution and their migration is indicated in some papers (Gasparon et Matschullat 2006, Bargagli 2008). Available data shows significant variability in the content of trace elements in natural undisturbed and unexposed Antarctic soils (Santos et al. 2005, Padeiro et al. 2014, De Lima Neto et al. 2017, Smykla et al. 2018) - see the Appendix. Not considering in detail the differences in the properties of the Antarctic soils, we should mention only some of the contrasting values which are known now: for example, non-humus and organic (ornithogenic) soils, acid and alkaline, dry and waterlogged, etc. In other words, according to the range of these indicators only, one can judge the diversity of natural factors and their combinations, characteristic of the oases of Antarctica.

As it was shown above and in Appendix, the contaminated soils have a very 
clear connection with sources of pollutants, most often waste and / or fuel spills (Amaro et al. 2015, Parnikoza et al. 2016, De Lima Neto et al. 2017). Recorded extremely high metal concentrations in soils at fire sites, reaching several grams per kilogram of soil according to the data (Guerra et al. 2011, Guerra et al. 2013), refer to exceptional cases; probably the sources of pollution were the burning station's debris. Among the list of pollution sources, paints from old painted surfaces of abandoned buildings (Pertierra et al. 2013) as well as

\section{Conclusion}

New data on the content of trace elements in soils and bottom sediments of the Vecherny oasis are summarized. It is shown that variability of content values can be caused by both natural and anthropogenic factors. Among the most important natural factors determining the initial concentrations of trace elements is the composition and properties of parent rocks.

The cases of elevated concentrations of $\mathrm{Cd}, \mathrm{Pb}$ and $\mathrm{Zn}$ in soils and $\mathrm{Cd}, \mathrm{Cu}, \mathrm{Ni}, \mathrm{Pb}$ and $\mathrm{Zn}$ in the bottom sediments of the Vecherny oasis confirm, on the one hand, the migration and redistribution of chemicals with melt water flows, and, on the other, the influence of previous human activities related to the functioning of the field base in the 1980-1990's (possibility of current human activity influence is not excluded). In comparison with other oases of Antarctica, no hotspots have been revealed and no significant areas of soil contamination have been identified yet, which is largely due to the fragmentation of the soil cover and lack of significant sources of pollution.

Assessment of the trace element accu- field seasonal bases (De Lima Neto et al. 2017) are indicated. As a secondary source of soil contamination penguins are considered, as far as soil contamination at penguins nesting areas was detected (Celis et al. 2015, Vlček et al. 2017, Cipro et al. 2018).

Generally, in comparison with the soils of most studied regions of Antarctica (Antarctic Peninsula, Fields Peninsula, Ross Islands, King George, McMurdo Dry Valleys), the soils of the Vecherny oasis has a relatively low trace elements content.

mulation in soil is complicated because of only the preliminary data has been received for this region. It is necessary to continue research in this oasis with an emphasis on clarification of background values of trace elements, considering the fragmentation of soils, slow pedogenesis as well as the subsequent evaluation of their accumulation due to the functioning of Belarusian Antarctic station.

To estimate the level of pollution and its danger, threshold values (Maximum Permissible Levels) elaborated in Belarus or in other countries can hardly been directly applied for the Antarctic soils taking into account their specific properties as well as Antarctic biota high vulnerability and sensitivity. Establishing of critical loads and thresholds values for the Antarctic soils is a one of the task for future investigation involving full-scale study of soilbiota relationships, mapping and modeling ([1] - ATCM XL IP005, 2017). Regulation of anthropogenic loads will help to prevent irreversible changes in unique polar ecosystems within stations location. 


\section{References}

Aleksandrov, M. V. (1985): Landscape structure and mapping of oasis of Enderby Land. Leningrad: Gidrometeoizdat, 152 p. (In Russian).

Amaro, E., Padeiro, A., De Ferro, A. M., Mota, A.M., Leppe, M., Verkulich, S., Hughes, K., Peter H.-U. and CANÁRIO, J. (2015): Assessing trace element contamination in Fildes Peninsula (King George Island) and Ardley Island, Antarctic. Marine Pollution Bulletin, 97: 523-527.

BARGAGLI, R. (2000): Trace metals in Antarctica related to climate change and increasing human impact. Reviews of Environmental Contamination and Toxicology, 166: 129-173.

BARGAGLI, R. (2008): Environmental contamination in antarctic ecosystems. Science of the Total Environment, 400: 212-226.

BockHEIM, J. G. (2015): Soil-forming factors in Antarctica. In: J. G. Bockheim (Ed.): The Soils of Antarctica. Basel: Springer International, pp.5-20. DOI 10.1007/978-3-319-05497-1 2

Braun, C., Hertel, F., Mustafa, O., Nordt, A., Pfeiffer S. and Peter. H.-U. (2014): Environmental assessment and management challenges of the Fildes Peninsula region. In: T. Tin, D. Liggett, P.T. Maher, M. Lamers (eds.): Antarctic Futures. Springer, Dordrecht, pp.169191.

Campbell, I. B., Claridge, G. G. C. (1987): Antarctica: Soils, weathering processes and environment. Elsevier. 407 p.

Celis, J.E., Barra, R., Espejo, W., GonzÁlez-Acuña, D. and Jara, S. (2015): Trace element concentrations in biotic matrices of gentoo penguins (Pygoscelis papua) and coastal soils from different locations of the Antarctic Peninsula. Water, Air, \& Soil Pollution, 226: 2266.

Chaparro, M. A. E., Nunez, H., Lirio, J. N. M, Gogorza, C. S. G. and Sinito, A. M. (2007): Magnetic screening and heavy metal pollution studies in soils from Marambio station, Antarctica. Antarctic Science, 19(3): 379-393.

Chen, J., Blume, H-P. (1995): Impact of human activities on the terrestrial ecosystem of Antarctica: A Review. Polarforschung, 65(2): 83-92.

Cipro, C. V. Z., Bustamante, P., Petry, M. V. and Montone, R. C. (2018): Seabird colonies as relevant sources of pollutants in Antarctic ecosystems: Part 1 - Trace elements. Chemosphere, 204: 535-547.

Claridge, G. G. C., Campbell, I. B., Powell, H. K. J., Amin, Z. H. and Balks, M. R. (1995): Heavy metal contamination in some soils of the McMurdo Sound Region, Antarctica. Antarctic Science, 7(1): 9-14.

Crockett, A. B. (1998): Background levels of metals in soils, McMurdo station, Antarctica. Environmental Monitoring and Assessment, 50: 289-296.

Culicov, O. A., Yurukova, L., Duliu, O. G. and Zinicovscaia, I. (2017): Elemental content of mosses and lichens from Livingston Island (Antarctica) as determined by instrumental neutron activation analysis (INAA). Environmental Science and Pollution Research International, 24: $5717-5732$.

De Lima Neto, E., Guerra, M. B. B., Thomazini, A., Daher, M., De Andrade A. M. and SCHAEFER, C. E. G. R. (2017): Soil contamination by toxic metals near an Antarctic refuge in Robert Island, Maritime Antarctica: A Monitoring strategy. Water, Air, \& Soil Pollution, 228: 66. doi: 10.1007/s11270-017-3245-4.

Dolgikh, A. V, Mergelov, N. S, Abramov, A. A, Lupachev, A. V. and Goryachion, S. V. (2015): Soils of Enderby Land. In: J. G. Bockheim (ed.): The Soils of Antarctica. Basel: Springer International, pp. 45-63.

Fryirs, K. A., HafsteinsdótTiR, E. G., StARK, S. C. and Gore, D. B. (2015): Metal and petroleum hydrocarbon contamination at Wilkes station, East Antarctica. Antarctic Science, 27(2): 118133.

Gasparon, M., Matschullat, J. (2006): Trace metals in Antarctic ecosystems: Results from the Larsemann Hills, East Antarctica. Applied Geochemistry, 21(9):1593-1612

Guerra, M. B. B., Schaefer, E. C. G. R., Rosa, P. F., Simas F. N. B., Pereira, T. T C. and PereirA-Filho, E. R. (2011): Heavy metals contamination in century-old manmade technosols 
of Hope Bay, Antarctic Peninsula. Water, Air, \& Soil Pollution, 222: 91-102. doi: 10.1007/s11270011-0811-z.

Guerra, M. B. B., Lima Neto, E., Prianti, M. T. A., Pereira-Filho, E. R. and Schaefer, C. E. G. R. (2013): Post-fire study of the Brazilian Scientific Antarctic Station: Toxic element contamination and potential mobility on the surrounding environment. Microchemical Journal, 110: 21-27.

Kabata-Pendias, A. (2010): Trace elements in soils and plants, $4^{\text {th }}$ edition, CRC Press. 548 p. http://dx.doi.org/10.1201/b10158-25.

Kabata-Pendias, A., Pendias, H. (2001): Trace elements in soils and plants. CRC Press, Boca Raton, FL ( $3^{\text {rd }}$ edition), $413 \mathrm{p}$.

KarataeV. G. I, GaReTSKY, R. G. (2011): Tectonics of the northeast part of the East Antarctic Platform). In: V. P. Samodurov (Ed.): Actual problems of geology and prospecting for mineral deposits. Proceedings of University Geological Readings. Minsk: BSU, pp.11-14.

Kennicutt II, M. C., Klein, A., Montagna, P., Sweet S., Wade, T., Palmer, T., Sericano, J. and DenouX, G. (2010): Temporal and spatial patterns of anthropogenic disturbance at McMurdo station, Antarctica. Environmental Research Letters, 5(3): 1-10.

Kostova, I., Apostolova, D., Filcheva, E., Klain, L. and Popov, M. (2015): Geochemical composition and properties of Antarctic soil samples from Livingston Island. Annual of the University of Mining and Geology "St. Ivan Rilski", Part I, Geology and Geophysics, 58: 107116.

KuKharchy,, T. I., KaKareKa, S. V. (2016): Composition and properties of soils near Mount Vechernyaya (Enderby Land, East Antarctica). Doklady of the National Academy of Sciences of Belarus, 60 (1): 87-93.

Lu, Z., CAI, M., WANG, J., YANG, H. and HE, J. (2012): Baseline values for metals in soils on Fildes Peninsula, King George Island, Antarctica: The Extent of Anthropogenic Pollution. Environmental Monitoring and Assessment, 184(11): 7013-7021.

MacNamara, E. E. (1969): Pedology of Enderby Land, Antarctica. Antarctic Journal, 208-210.

Malandrino, M., Abollino, O., Buoso, S., Casalino, C., Gasparon, M., Giacomino, A., Gioia, C., and Mentasti, E. (2009): Geochemical characterization of Antarctic soils and lacustrine sediments from Terra Nova Bay. Microchemical Journal, 92: 21-31.

Mergelov, N. S, Konyushiov, D. E, Lupachev, A.V and Goryachion, S. V. (2015): Soils of MacRobertson Land. In: J. G. Bockheim (Ed.): The soils of Antarctica. Basel Springer International, pp 65-86.

Mergelov, N. S. (2014): Soils of the Wet Valleys in Larsemann and Vestfold Hills (Princess Elizabeth Land, East Antarctica). Eurasian Soil Science, 47(9): 845-862.

MyASNiKOV, O. V. (2011): Geological structure of the territory of Vechervnaya Mount Enderby Land, Antarctica. In: V. P. Samodurov (ed.): Actual problems of geology and prospecting for mineral deposits. Proceedings of University Geological Readings. Minsk: BSU, pp.17-20.

O'Neill, T. A. (2017): Protection of Antarctic soil environments: A review of the current issues and future challenges for the environmental protocol. Environmental Science and Policy, 76: 153-164.

O’Neill, T. A., Aislabie, J. and Balks, M. R. (2015): Human impacts on soils. In: J. G. Bockheim (ed.): The Soils of Antarctica, World Soils Book Series. Springer, pp. 281-303.

Padeiro, A., Amaro, E., Dos Santos, M. M., Araújo, M. F., Gomes, S. S., Leppe, M., Verkulich, S., Hughes, K. A., Peter, H. U. and CanÁrio, J. (2016): Trace element contamination and availability in the Fildes Peninsula, King George Island, Antarctica. Environmental Science: Processes and Impacts, 18: 648-657.

Padeiro, A., SAntos, M. C. and CANÁRIo, J. (2014): Soil contamination in Fildes Peninsula (King George Island, Antarctic): Bio(availability) and remediation strategies. pp. 1-7.

Parnikoza, I., Abakumov, E., Korsun, S., Klymenko, I., Netsyk, M., Kudinova, A. and Kozeretska, I. (2016): Soils of the Argentine Islands, Antarctica: Diversity and characteristics. Polarforschung, 86(2): 83-96.

Pertierra, L. R., Hughes, K. A., Benayas, J., Justel, A. and Quesada, A. (2013): Environmental management of a scientific field camp in maritime Antarctica: Reconciling 
T. KUKHARCHYK et al.

research impacts with conservation goals in remote ice-free areas. Antarctic Science, 25(2): 307-317. doi:10.1017/S0954102012001083.

Rudnic, R. L., GaO, S. (2003): Composition of the continental crust. In: H. D. Holland, K. K. Turekian (eds): Treatise on geochemistry, vol. 3. Elsevier-Pergamon, Oxford, London, pp. 164.

Santos, I. R., Silva, E. V., Schaefer, C. E. G. R., Alburquerque, M. R. and Ampos, L. S. (2005): Heavy metal contamination in coastal sediments and soils near the Brazilian Antarctic Station, King George Island. Marine Pollution Bulletin, 50: 185-194.

Sheppard, D. S., Claridge, G. G. C. and Campbell, I. B. (2000): Metal contamination of soils at Scott Base, Antarctica. Applied Geochemistry, 15: 513-530.

SimONOv, I. M. (1971): Oasis of earth Antarctic. Leningrad: Gidrometeoizdat, 180 p. (In Russian)

Smykla, J., Szarek-Gwiazda, E., Drewnik, M., KNAP, W. and EMSlie, S. D. (2018): Natural variability of major and trace elements in non-ornithogenic gelisols at Edmonson Point, Northern Victoria Land, Antarctica. Polish Polar Research, 39(1): 19-50, doi: 10.24425/118737.

Snape, I., Stark, J. S., Cole, C. M., Gore, D. G., Duquesne, S. and Riddle, M. J. (2001): Management and remediation of contaminated sites at Casey Station, Antarctica. Polar Record, 37: 199-214.

Stark, S. C., Snape, I., Graham, N. J., Brennan, J. C. and Gore, D. B. (2008): Assessment of metal contamination using x-ray fluorescence spectrometry and the Toxicity Characteristic Leaching Procedure (TCLP) during remediation of a waste disposal site in Antarctica. Journal of Environmental Monitoring, 10: 60-70.

SzOPINSKA, M., NAMIESNIK, J. and POLKOWSKA, Z. (2016): How important is research on pollution levels in Antarctica? Historical approach, difficulties and current trends. In: P. de Voogt (ed.): Reviews of Environmental Contamination and Toxicology, Volume 239, Springer International Publishing, pp.79-156.

TAYLOR, P. K. (2015): Residual contamination and environmental effects at the Former Vanda Station, Wright Valley, Antarctica. Master of Water Resource Management Thesis. New Zealand. $108 \mathrm{p}$

Tin, T., Fleming, Z. L., Hughes, K. A., Ainley, D. G., Convey, P., Moreno, C. A., Pfeiffer, S., ScOTT, J. and Snape, I. (2009): Impacts of local human activities on the Antarctic environment. Antarctic Science, 21(1): 3-33.

Ugolini, F. C., Bockheim, J. G. (2008): Antarctic soils and soil formation in a changing environment: A Review. Geoderma, 144: 1-8.

VLČEK, V., JUŘIČKA, D. and MíKOVÁ, J. (2017): Heavy metal concentration in selected soils and sediments of Livingston Island, Deception Island, King George Island, James Ross Island (Antarctica). Czech Polar Reports, 7(1): 18-33.

Webster, J., Webster, K., Nelson, P. and Waterhouse, E. (2003): The behaviour of residual contaminants at a Former Station Site, Antarctica. Environmental Pollution, 123(2): 163-179.

Zazovskaya, E., Mergelov, N., Shishkov, V., Dolgikh, A. Miamin, V., Cherkinsky, A. and GoRYACHKIN, S. (2016): Radiocarbon age of soils in oases of east Antarctica. Radiocarbon, pp. 1-15.

ZvěŘina, O., Coufalík, P., Vaculovič, T., Kuta, J. Zeman, J. and KomÁReK, J. (2012): Macroand microelements in soil profile of the moss-covered area in James Ross Island, Antarctica. Czech Polar Reports, 2(1): 1-7.

\section{Web sources / Other sources}

[1] ATCM XL IP005 (2017). Towards establishing of values of critical loads and thresholds for the Antarctic environment. XL Antarctic Treaty Consultative Meeting, China, 2017// Available at: https://www.ats.aq/devAS/ats_meetings_doc_database.aspx?lang=e\&menu=2 


\section{Appendix:}

Content of heavy metals is soils of different Antarctic stations (survey of published data).

\begin{tabular}{|c|c|c|c|c|c|c|c|c|c|}
\hline Location & Cd & $\mathrm{Cr}$ & $\mathrm{Cu}$ & Mn & $\mathbf{N i}$ & $\mathbf{P b}$ & V & Zn & Reference \\
\hline \multicolumn{10}{|c|}{ Background territories } \\
\hline $\begin{array}{l}\text { Robert Is- } \\
\text { land, South } \\
\text { Shetland } \\
\text { Islands }\end{array}$ & $<0.2$ & 52 & 47.8 & 453 & 40.4 & 7.3 & 109 & 43.9 & $\begin{array}{l}\text { De Lima } \\
\text { Neto et al. } \\
2017\end{array}$ \\
\hline $\begin{array}{l}\text { The Collins } \\
\text { Glacier, } \\
\text { Fildes } \\
\text { Peninsula, } \\
\text { King } \\
\text { George } \\
\text { Island }\end{array}$ & 0.2 & $28-31$ & $49-70$ & - & $12-18$ & $5-7$ & & $56-87$ & $\begin{array}{l}\text { Padeiro et } \\
\text { al. } 2014\end{array}$ \\
\hline $\begin{array}{l}\text { Ferraz sta- } \\
\text { tion, King } \\
\text { George } \\
\text { Island }\end{array}$ & - & 40 & 44 & 442 & 5.1 & 12 & 91 & 52 & $\begin{array}{l}\text { Santos et } \\
\text { al. } 2005\end{array}$ \\
\hline $\begin{array}{l}\text { Edmonson } \\
\text { Point, } \\
\text { Victoria } \\
\text { Land }\end{array}$ & 0.21 & 7.8 & 3.9 & 380 & 33.6 & 1.7 & 11.2 & 42.9 & $\begin{array}{l}\text { Smykla et } \\
\text { al. } 2018\end{array}$ \\
\hline $\begin{array}{l}\text { Terra Nova } \\
\text { Bay, } \\
\text { Victoria } \\
\text { Land }\end{array}$ & 0.4 & 54 & 25 & - & 19 & 19 & & - & $\begin{array}{l}\text { Malandrino } \\
\text { et al.2009 }\end{array}$ \\
\hline $\begin{array}{l}\text { The Hurd } \\
\text { Peninsula of } \\
\text { the } \\
\text { Livingstone } \\
\text { Island }\end{array}$ & - & 36 & - & 1100 & 14 & - & 190 & 110 & $\begin{array}{l}\text { Culicov et } \\
\text { al. } 2017\end{array}$ \\
\hline \multicolumn{10}{|c|}{ Impact areas } \\
\hline $\begin{array}{l}\text { Robert } \\
\text { Island, } \\
\text { South } \\
\text { Shetland } \\
\text { Islands, near } \\
\text { wastes }\end{array}$ & $<0.2$ & 72 & 107 & 545 & 37.9 & 102 & 122 & 148 & $\begin{array}{l}\text { De Lima } \\
\text { Neto et al. } \\
2017\end{array}$ \\
\hline $\begin{array}{l}\text { Hope Bay, } \\
\text { Antarctic } \\
\text { peninsula, } \\
\text { after the fire } \\
\text { at British } \\
\text { station }\end{array}$ & 50 & - & 2100 & - & - & 19380 & - & 5200 & $\begin{array}{l}\text { Guerra et } \\
\text { al. } 2011\end{array}$ \\
\hline $\begin{array}{l}\text { Fildes Bay, } \\
\text { near fuel } \\
\text { tanks }\end{array}$ & 0.5 & - & 30 & - & - & - & - & 154 & $\begin{array}{l}\text { Amaro et } \\
\text { al. } 2015\end{array}$ \\
\hline $\begin{array}{l}\text { Ferraz } \\
\text { station, after } \\
\text { fire, alarm- } \\
\text { ing levels }\end{array}$ & - & 1600 & 34000 & 6800 & 15.9 & 13700 & 250 & 42200 & $\begin{array}{l}\text { Guerra et } \\
\text { al. } 2013\end{array}$ \\
\hline
\end{tabular}




\begin{tabular}{|c|c|c|c|c|c|c|c|c|c|}
\hline $\begin{array}{l}\text { McMurdo } \\
\text { station, } \\
\text { Gray soil }\end{array}$ & 0.13 & 172 & 39 & - & 98 & 5.8 & - & 115 & $\begin{array}{l}\text { Crockett } \\
1998\end{array}$ \\
\hline $\begin{array}{l}\text { O'Higgins } \\
\text { Base }\end{array}$ & 4.3 & 65 & 422 & 405 & 28 & 282 & - & 485 & $\begin{array}{l}\text { Celic et al. } \\
2015\end{array}$ \\
\hline $\begin{array}{l}\text { Fildes } \\
\text { Peninsula, } \\
\text { King } \\
\text { George } \\
\text { Island }\end{array}$ & $\begin{array}{l}0.04- \\
0.34\end{array}$ & $\begin{array}{l}17.1- \\
64.9\end{array}$ & $\begin{array}{l}51.1- \\
176.5\end{array}$ & $\begin{array}{l}449- \\
1400\end{array}$ & $\begin{array}{l}7.2- \\
25.0\end{array}$ & $\begin{array}{l}2.8- \\
60.5\end{array}$ & & $\begin{array}{l}41.6- \\
80.6\end{array}$ & $\begin{array}{l}\text { Lu et al. } \\
2012\end{array}$ \\
\hline $\begin{array}{l}\text { Fildes } \\
\text { Peninsula, } \\
\text { King } \\
\text { George } \\
\text { Island }\end{array}$ & $\begin{array}{l}0.2- \\
1.2\end{array}$ & $\begin{array}{l}15- \\
263\end{array}$ & $\begin{array}{l}56- \\
179\end{array}$ & - & $\begin{array}{l}12- \\
141\end{array}$ & $3-418$ & & $\begin{array}{l}68- \\
949\end{array}$ & $\begin{array}{l}\text { Padeiro et } \\
\text { al. } 2014\end{array}$ \\
\hline $\begin{array}{l}\text { The } \\
\text { Bulgarian } \\
\text { Antarctic } \\
\text { Base, } \\
\text { Livingston } \\
\text { Island }\end{array}$ & $\begin{array}{l}3.7- \\
4.7\end{array}$ & $\begin{array}{l}42.9- \\
59.5\end{array}$ & $\begin{array}{l}50- \\
50.8\end{array}$ & - & $\begin{array}{l}32.5- \\
33.6\end{array}$ & $\begin{array}{l}8.3- \\
44\end{array}$ & $\begin{array}{l}91- \\
224\end{array}$ & $\begin{array}{l}86.8- \\
199.7\end{array}$ & $\begin{array}{l}\text { Kostova et } \\
\text { al. } 2015\end{array}$ \\
\hline $\begin{array}{l}\text { Marina } \\
\text { Point near } \\
\text { Diesel } \\
\text { station, } \\
\text { Galindez } \\
\text { Island of the } \\
\text { Argentine } \\
\text { Islands }\end{array}$ & 20.9 & - & 1856 & 77.1 & 12.2 & 741 & - & 667 & $\begin{array}{l}\text { Parnikoza } \\
\text { et al. } 2016\end{array}$ \\
\hline $\begin{array}{l}\text { Chilean } \\
\text { Bernardo } \\
\text { o'Higgins, } \\
\text { Antarctic } \\
\text { Peninsula }\end{array}$ & - & 5 & 201 & - & 4 & 21 & 39 & 771 & $\begin{array}{l}\text { Vlček et al } \\
2017\end{array}$ \\
\hline
\end{tabular}

